\title{
MENINGKATKAN HASIL BELAJAR IPA KONSEP LISTRIK DINAMIS DENGAN MODEL INDUKSI SISWA
}

\author{
LILIK PUJI ASTUTIK \\ MTsN 15 Jombang \\ e-mail: lilikpuji029@gmail.com
}

Kenyataan yang dijumpai di lapangan menunjukkan bahwa masih banyak siswa yang belum memahami dan mengaplikasikan konsep IPA yang berhubungan dengan numerik terutama materi listrik dinamis. Hal ini ditunjukkan dari nilai rata-rata yang sangat rendah. Untuk mengatasi permasalahan tersebut dilakukan upaya oleh peneliti dalam meningkatkan hasil belajar siswa melalui model induksi siswa yang dipadupadankan dengan teori penerapan model pembelajaran kooperatif tipe TAI (Team Assisted Individualization). Jenis penelitian ini adalah penelitian kualitatif, dengan desain penelitian perencanaan, pelaksanaan, pengamatan dan refleksi. Berdasarkan temuan permasalahan pada identifikasi awal, disusun rencana tindakan perbaikan masalah-masalah yang ditemui dalam proses pembelajaran IPA. Adapun langkah yang dilakukan sebagai berikut. Pertama, peneliti menyusun rencana dengan metode meliputi; (1) penetapan standar kompetensi, indikator dan tujuan pembelajaran, (2) menentukan meteri atau bahan ajar, (3) menetapkan mentode dan teknik pembelajran, (4) menentukan media pembelajaran, (5) melakukan kegiatan pembelajaran yang berupa kegiatan pendahuluan, kegiatan inti dan penutup, dan (6) evaluasi pembelajaran. Kedua, menyususn indikator dan kreteria pencapaian siswa dalam pembelajaran. Ketiga, menyususn pendoman pengamatan dan format pengamatan. Data yang diambil dalam penelitian ini merupakan data angket motivasi siswa, observasi tindakan siklus 1, 2 dan 3 serta data pendukung lainnya. Dari hasil penelitian diperoleh data perubahan tingkat pemahaman siswa menjadi lebih baik. Hal ini terlihat dari perubahan rerata kelas 43,78 pada siklus 1 skor hasil belajar memperoleh rerata 44,82, siklus 2 skor rerata 65,09 dan siklus 3 skor rerata 83,39. Model pembelajaran induksi siswa (dalam hal ini perpaduan dengan model TAI) terbukti dapat meningkatkan hasil belajar siswa. Hal ini ditunjukkan dengan peningkatan rata-rata skor aktivitas belajar sebelum menggunakan model induksi mendapatkan skor rerata 43,78, kemudian pada siklus 1 skor aktivitas belajar memperoleh rerata 44,82, siklus 2 skor rerata 65,09 dan siklus 3 skor rerata 83,39. Ketuntasan belajar juga mengalami peningkatan yang semula $61,05 \%$ menjadi 80,00 $\%$. Dari hasil penelitian pembelajaran dengan menggunakan model induksi siswa mampu meningkatkan hasil belajar siswa materi listrik dinamis mata pelajaran IPA di kelas IX C MTsN 15 Jombang semester ganjil tahun pelajaran 2019/2020.

Kata kunci: listrik dinamis, model induksi siswa. 


\section{PENDAHULUN}

Pendidikan memegang peranan penting untuk menjamin kelangsungan hidup suatu negara dan bangsa (Herlanti, Rustaman, Rohman, \& Fitriani, 2012). Pendidikan menuntut guru untuk mengembangkan potensi siswa berdasarkan standar kompetensi yang ada. (Yulianti \& Putra, 2012). Pendidikan yang bermutu, akan menghasilkan sumber daya manusia yang berkualitas dan berdaya saing tinggi. (Gumrowi, 2016). Kualitas pendidikan, sangat penting dalam pengembangan sumber daya manusia. Masa depan bangsa bergantung pada keberadaan pendidikan yang berkualitas yang berlangsung di masa ini. Pendidikan yang berkualitas bisa muncul dari madrasah yang memberikan pengalaman belajar yang bermakna. Dengan kata lain upaya peningkatan kualitas madrasah adalah tindakan yang terus ditingkatkan. kapanpun, dimanapun dan dalam kondisi apapun. Upaya yang dilakukan untuk meningkatkan kualitas pembelajaran yang menuntut guru untuk dapat memberikan hasil belajar maksimal melalui suatu proses pembelajaran yang tepat. Tugas utama guru adalah bertanggung jawab membantu siswa dalam memecahkan masalah terutama yang terjadi di dalam kelas, membuat evaluasi belajar siswa, baik sebelum, sedang, dan sesudahnya.

Proses pembelajaran itu sendiri berupa hubungan interaksi antara siswa, guru, perlengkapan dan kurikulum. Suatu kegiatan pembelajaran dapat dikatakan berjalan dengan baik dan efektif apabila hubungan interaksi tersebut dapat saling mendukung. Guru sebagai salah satu komponen hubungan interaksi pada proses pembelajaran, bertugas membimbing dan mengarahkan siswa belajar dan bagaimana supaya mendapatkan hasil belajar yang maksimal. Besar kecilnya peranan guru dalam proses pembelajaran untuk mencapai hasil belajar yang baik sangat tergantung pada tingkat penguasaan materi, pemilihan pendekatan, metode yang digunakan dan model pembelajaran yang akan dipakai. (Khusaini, 2017). Sains tidak hanya menyampaikan apa yang kita ketahui, tetapi lebih jauh lagi bagaimana kita menjadi tahu dan mengapa kita mempercayainya. (Herlanti et al., 2012). Proses mengingat kembali tentang apa yang telah terlupa dan mengingat untuk memahami ilmu pengetahuan baru dalam proses berpikir seseorang (Saregar, Latifah, \& Sari, 2016).

Proses pembelajaran yang baik seharusnya banyak melibatkan siswa, sehingga siswa mempunyai peran penting dalam kegiatan belajar mengajar. Tetapi, dilihat dari kondisi siswa saat proses pembelajaran sering ditemukan hampir keseluruhan siswa banyak terdiam diri dan kurang percaya diri dalam mengeluarkan pendapatnya. Apabila guru memberikan pertanyaan dijawab serentak, hal ini membuktikan bahwa siswa kurang percaya diri dalam menjawab pertanyaan secara individu. Siswa juga tidak berani bertanya kepada guru jika tidak mengerti padahal guru telah memberikan kesempatan dan mereka lebih berani bertanya kapada sesama temannya. Kemudian saat guru bertanya hanya siswa-siswa tertentu yang merespon yang lainnya berdiam diri dan mengerjakan kegiatan lainya yang tidak berhubungan dengan pembelajaran yang berlangsung. (Wardani, Suwatra, \& Wirya, 2015) pada mata Pelajaran Ilmu Pegetahuan Alam (IPA) rata-rata di MTsN 15 Jombang anak masih mendapatkan nilai di bawah KKM terutama yang berhubungan dengan konsep numerik. Hasil rata-rata penilaian harian (PH) siswa 43,78 masih di bawah KKM 76. Hal inilah peneliti tergerak untuk mengatasi permasalahan yang terjadi pada siswa kelas IX C MTsN 15 Jombang 
yang mengambil salah satu konsep numerik materi listrik dinamis dengan memadu padankan model pembelajaraan kooperatif tipe TAI.

Pembelajaran kooperatif tipe TAI ini merupakan suatu model pembelajaran yang mengkombinasikan pembelajaran kooperatif dengan pembelajaran individual (Hermawan \& Paloloang, 2014; Saregar, Diani, \& Kholid, 2017). Model pembelajaran kooperatif dapat melibatkan siswa secara aktif diantaranya adalah Team Assisted Individualization. Dalam model pembelajaran Team Assisted Individualization (TAI) adalah siswa dituntuk aktif dalam kelompoknya. (Abidin, 2013) menyebutkan beberapa kelebihan dan kelemahan model pembelajaran kooperatif tipe Team Assisted Individualization (TAI), kelebihannya diantaranya : 1) siswa akan termotivasi belajar karena hasil belajar dinilai secara teliti dan cepat, 2) para siswa terbina kemampuan komunikasinya, 3) perilaku yang mengganggu dan konflik antar pribadi akan terkurangi melalui penanaman prinsip kerja kooperatif, 4) program ini sangat membantu siswa yang lemah dan sekaligus meningkatkan prestasi belajar siswa secara keseluruhan karena dapat secara langsung bertanya pada temannya. Sedangkan kelemahan Model Pembelajaran Kooperatif Tipe Team Assisted Individualization (TAI) diantaranya: 1) diperlukan media pembelajaran yang lengkap dan memadai, 2) waktu yang lama untuk pembuatan perangkat pembelajaran, 3) diperlukan kinerja kritis evaluatif dari guru selama siswa bekerja dalam kelompok.

Siswa setingkat SMP/MTs adalah usia remaja yang lebih suka bertanya pada teman daripada gurunya. Kenyataan ini ditunjukkan pada siswa kelas IX C saat peneliti mengajar mata pelajaran IPA. Siswa yang tidak paham bukan bertanya pada melainkan pada teman yang dianggapnya lebih mampu atau teman sebangkunya atau bahkan temannya sama-sama tidak tahu. Hal ini diperjelas dengan hasil pengamatan kami pada guru mata pelajaran lainya. Permasalahan utama yang dihadapi peneliti (guru) di kelas ini adalah siswa sangat sulit diajak berinteraksi di dalam proses pembelajaran. Kelas ini menunjukkan sikap diam dan pasif serta jika ada pertanyaan maka cenderung bertanya pada temannnya. Hal inilah salah satu yang menyebabkan hasil evaluasi belajar mereka masih sangat rendah. Lemahnya pemahaman siswa terhadap materi Listrik Dinamis disebabkan kurang tepatnya model pembelajaran yang digunakan. Akhirnya peneliti mencoba menggunakan model pembelajaran model induksi siswa. Model induksi siswa yang melibatkan siswa untuk melakukan sendiri aktivitas belajar sehingga semua yang diperoleh akan mudah diingat dan dipahami.

Interaksi dalam proses pembelajaran adalah proses kegiatan interaksi antara dua unsur manusia yakni siswa dengan siswa sebagai pihak yang belajar dan guru sebagai pihak yang mengajar dengan siswa sebagai objeknya. Oleh karena itu, seorang guru dan siswa dituntut untuk bisa melakukan interaksi dalam proses pembelajaran dengan baik, sehingga siswa mampu meningkatkan hasil belajar dengan maksimal (Rahayu, 2012) Induksi siswa terinpirasi dari materi induksi magnet. Induksi magnet adalah kuat medan magnet akibat adanya arus listrik yang mengalir dalam suatu konduktor (id.wikipedia.org/wiki/Induksi_magnet). Model induksi siswa merupakan upaya agar siswa yang mampu/tuntas belajar akan mentransferkan ilmunya kepada teman lainnya. Belajar seperti ni sesuai dengan konsep Kooperatif learning yang merupakan strategi belajar dengan sejumlah siswa sebagai anggota kelompok kecil yang tingkat kemampuannya berbeda. Dalam menyelesaikan tugas kelompoknya, 
setiap siswa anggota kelompok harus saling bekerja sama dan saling membantu untuk memahami materi pelajaran khususnya materi listrik dinamis. Berdasarkan latar belakang yang telah dikemukakan di atas maka tujuan penelitian ini adalah untuk mengetahui bagaimana cara meningkatkan hasil belajar IPA siswa kelas IX C materi listrik dinamis MTsN 15 Jombang Tahun Pelajaran 2019/2020 melalui model induksi siswa.

\section{METODE PENELITIAN}

Penelitian ini merupakan penelitian deskriptif karena medeskripsikan motivasi siswa, aktivitas belajar siswa dan ketuntasan hasil belajar siswa. Di samping itu jenis penelitian juga meruakan penelitian tindakan, karena berdasar pernasalahanpermasalahan yang dihadapi penelitim(guru) di dalam kelas dan ada tindakan untuk memperbaiki proses yang berdampak langsung pada pembelajaran (Arikunto, 2006).

Penelitian ini merupakan pengembangan metode dan strategi pembelajaran. Model Team Assisted Individualization (TAI) merupakan salah satu dari model pembelajaran kooperatif yang di bentuk dari kelompok-kelompok kecil dalam kelas yang heterogen dalam setiap kelompok dan diikuti dengan pemberiaan bantuan dari siswa yang pandai anggota kelompok secara individual bagi peserta didik yang memerlukan. (Tinungki, 2015). Yang kami padupadankan dengan model induksi siswa. Subjek Penelitian ini adalah siswa kelas IX C MTsN 15 Jombang pada semester 1 tahun pelajaran 2019/2020 sebanyak 32 siswa..

Penelitian ini mengikuti daur/siklus yang di dalamnya terdapat kegiatan perencanaan, pelaksanaan, pengamatan dan refleksi atas tindakan yang telah dilakukan sehingga peneliti harus mencatat tingkah laku siswa selama proses pembelajaran. Hasil pengamatan tersebut akan membantu peneliti mengatasi permasalahan di dalam kelas sehingga mampu memperbaiki proses, hasil penelitian yang berdampak langsung pada proses pembelajaran yang diinginkan. Observasi keaktifan siswa selama proses pembelajaran merupakan proses pengumpulan data yang dibutuhkan. Pengambilan data aktifitas siswa mengunakan angket di tiap siklus. Angket ini menggunakan matrik motivasi yang terdiri dari attention, relevance, confidence, dan satisfaction.

Penelitian ini mengunakan 3 siklus dengan RPP yang berbeda tiap siklus.. Tindakan pada siklus 1 disajikan sebagai berikut: pendahuluan, guru memberikan apersepsi tentang tentang listrik dinamis yang sebelumnya guru telah menjelaskan tentang listrik statis. Guru membentuk 4 kelompok secara acak tanpa berdasarkan tingkat kemampuan dan guru menentukan salah satu siswa sebagai induktornya/pemimpin secara sembarang. Guru membagi Lembar Kerja Siswa untuk kegiatan praktikum listrik dinamis. Masing-masing induktor memimpin jalannya praktikum dibawah pemantauan guru. Semua siswa dalam kelompok mengisi hasil pratikumnya pada Lembar Kerja Siswa, menyimpulkan hasil pengamatan kemudian dibandingkan dengan kelompok lain, menjawab semua pertanyaan yang tersedia, serta induktor bertugas memberi tanggapan pada kelompoknya dan guru memberi nilai hasil diskusi dan memberi umpan balik. Pada siklus 1 ini proses pembelajaran secara diskusi hasil pengamatan praktikum mengalami kendala tidak bisa berjalan lancar karena ada salah satu kelompok yang sangat aktif ada pula kelompok yang sangat pasif. Tindakan pada siklus 2 sama dengan siklus 1 tetapi dengan banyaknya siswa yang belum paham 
pada siklus 1, peneliti menambah jumlah induktornya menjadi 6,dengan memperhatikan nilai hasil belajar materi sebelumnya. Tiap kelompok akan terdiri berbagai tingkat kompetensinya, sehingga masing-masing kelompok beranggotakan 5 dan 2 kelompok beranggotakan 6 orang .Guru memberikan aturan diskusi, jika ada salah satu anggotanya kena remidi (di bawah KKM) maka seluruh anggota kelompok bertanggungjawab atas kegagalan dari temannya, mereka harus membantu mengajari dan juga menunggu teman yang diremidi sampai selesai. Kegiatan siklus 2 ini difokuskan pada upaya mengatasi kesulitan inductor membantu temannya mencapai ketuntasan. Induktor memberikan arahan pada teman tersebut dan sekaligus menjadi nara sumber pada kegiatan praktikum. Tindakan pada siklus 3 juga hampir sama dengan siklus 1 dan 2. Namun di siklus 3 ini guru menambah lagi induktornya menjadi 8 sehingga masing-masing induktor memimpin 3 orang anggota. Guru memberikan latihan soal numerik berdasarkan kegiatan praktikum tentang beda potensial listrik, arus listrik dan hambatan listrik. Siswa mendengarkan arahan dan penjelasan konsep tersebut dari masing-masing induktor. Masing-masing kelompok mengerjakan soal latihan dan berdiskusi memcahkan masalah. Jika tugas sudah selesai maka induktor mengambil semua pekerjaan anggotanya dan diserahkan ke guru.

\section{HASIL PENELITIAN DAN PEMBAHASAN}

Berdasarkan temuan permasalahan pada identifikasi awal, disusun rencana tindakan perbaikan masalah-masalah yang ditemui dalam proses pembelajaran IPA. Adapun langkah yang dilakukan sebagai berikut. Pertama, peneliti menyusun rencana dengan media meliputi; (1) penetapan standar kompetensi, indikator dan tujuan pembelajaran, (2) menentukan meteri atau bahan ajar, (3) menetapkan metode dan teknik pembelajran, (4) menentukan media pembelajaran, (5) melakukan kegiatan pembelajaran yang berupa kegiatan pendahuluan, kegiatan inti dan penutup, dan (6) evaluasi pembelajaran. Kedua, menyusun indikator dan kriteria pencapaian siswa dalam pembelajaran. Ketiga, menyususn pendoman pengamatan dan format pengamatan.

Penelitian pembelajaran model induksi siswa menggunakan statistik deskriptif yang berupa deskripsi skor rata-rata dan prosentase. Angket motivasi siswa terhadap model pembelajaran induksi secara ringkas dapat disajikan dalam tabel di bawah ini:

Tabel 1: Motivasi Siswa dengan pembelajaran oleh guru 4 induktor (RPP 1)

\begin{tabular}{|c|c|c|c|c|c|}
\hline \multirow{2}{*}{ No } & Kondisi & \multicolumn{4}{|c|}{ Kriteria } \\
\cline { 3 - 6 } & & positif & kategori & negatif & Kategori \\
\hline 1. & Attention (perhatian) & 49 & Tidak baik & 43,92 & Tidak baik \\
2. & Relevance (relevansi) & 45 & Tidak baik & 44,59 & Tidak baik \\
3. & Confidence(keyakinan) & 43 & Tidak baik & 48,65 & Tidak baik \\
4. & Satisfaction (kepuasan) & 46 & Tidak baik & 51,35 & Tidak baik \\
\hline & Rata-rata & 45,75 & Tidak baik & 47,12 & Tidak baik \\
\hline
\end{tabular}


Tabel 2: Motivasi Siswa dengan pembelajaran yang dilakukan oleh 6 induktor (RPP 2)

\begin{tabular}{|c|c|c|c|c|c|}
\hline \multirow{2}{*}{ No } & Kondisi & \multicolumn{4}{|c|}{ Kriteria } \\
\cline { 3 - 6 } & & positif & Kategori & Negatif & Kategori \\
\hline 1. & Attention (perhatian) & 66 & Cukup & 62,50 & Cukup \\
2. & Relevance (relevansi) & 60 & Cukup & 63,51 & Cukup \\
3. & Confidence (keyakinan) & 69 & Cukup & 64,36 & Cukup \\
4. & Satisfaction (kepuasan) & 62 & Cukup & 64,86 & Cukup \\
\hline & Rata-rata & 63,75 & Cukup & 63,81 & Cukup \\
\hline
\end{tabular}

Tabel 3: Motivasi Siswa dengan pembelajaran yang dilakukan 8 induktor (RPP 3)

\begin{tabular}{|c|c|c|r|c|c|}
\hline \multirow{2}{*}{ No } & Kondisi & \multicolumn{4}{|c|}{ Kriteria } \\
\cline { 2 - 6 } & & Positif & kategori & negatif & Kategori \\
\hline 1. & Attention(perhatian) & 81 & baik & 81,08 & Baik \\
2. & Relevance (relevansi) & 76 & baik & 77,03 & baik \\
3. & Confidence (keyakinan) & 72 & baik & 82,88 & baik \\
4. & Satisfaction (kepuasan) & 73 & baik & 78,38 & baik \\
\hline & Rata-rata & 75,5 & baik & 79,84 & Baik \\
\hline
\end{tabular}

Tabel di atas menunjukkan skor rata-rata motivasi siswa tiap siklus. Angket motivasi belajar siswa berisi pernyataan-pernyataan yang mengandung kalimat positif (kriteria positif) dan kalimat negatif (krtiteria negatif). Dengan demikian pernyataan motivasi belajar yang positif dengan kategori baik berarti belajarnya baik. Sedangkan pada kriteria negatif jika pernyataan motivasi belajar positif dengan kriteria baik berarti aktivitas belajarnya baik. Hasil perhitungan rata-rata motivasi belajar siswa terhadap proses pembelajaran menunjukkan bahwa pembelajaran yang dilakukan oleh 8 induktor paling berhasil daripada dengan menggunakan 6 dan 4 induktor, apalagi jika proses pembelajaran hanya dilkukan oleh seorang guru saja. Data aktivitas siswa dalam pembelajaran dengan model induksi siswa diperoleh dari hasil pengamatan dengan menggunakan lembar pengamatan. Prosentase aktivitas siswa secara ringkas dituliskan pada table di bawah ini.

Tabel 3 : Prosentase aktivitas dalam proses pembelajaran model induksi siswa

\begin{tabular}{|c|l|c|c|c|}
\hline No & \multicolumn{1}{|c|}{ Aktivitas Siswa } & RPP 1 & RPP 2 & RPP 3 \\
\cline { 3 - 4 } & \multicolumn{1}{|c|}{ Prosentase } \\
\hline 1. & $\begin{array}{l}\text { Mendengarkan/ } \\
\text { memperhatikan penjelasan } \\
\text { guru untuk RPP 1 dan } \\
\text { mendengarkan / } \\
\text { memperhatikan penjelasan } \\
\text { siswa RPP 2,3 }\end{array}$ & 73,51 & 88,65 \\
\hline
\end{tabular}




\begin{tabular}{|c|l|r|r|r|}
\hline 2. & $\begin{array}{l}\text { Bekerja dengan menggunakan } \\
\text { alat, bahan dan berlatih } \\
\text { langsung soal-soal yang } \\
\text { tersedia }\end{array}$ & 53,05 & 65,88 & 80,00 \\
\hline 3. & $\begin{array}{l}\text { Menulis yang relevan dengan } \\
\text { materi pembelajaran }\end{array}$ & 50,68 & 70,95 & 88,51 \\
\hline 4. & $\begin{array}{l}\text { Berdiskusi dan bertanya antar } \\
\text { siswa }\end{array}$ & 30,33 & 54,05 & 82,49 \\
\hline 5. & Mengerjakan soal & 51,89 & 64,86 & 80,54 \\
\hline 6 & $\begin{array}{l}\text { Meyimpulkan materi pelajaran } \\
\text { pada hari ini }\end{array}$ & 39,19 & 61,26 & 80,18 \\
\hline Rata-rata & 44,82 & 65,09 & 83,39 \\
\hline
\end{tabular}

Dari tabel 4 di atas terlihat bahwa prosentase aktivitas rata-rata siswa dalam pembelajaran dengan model induksi siswa pada tiap-tiap RPP jelas terlihat semakin banyak induktor yang digunakan maka aktivitas siswa dalam pembelajaran akan semakin baik, artinya siswa lebih banyak mendominasi pada proses pembelajaran ( student oriented). Dengan kondisi seperti ini maka pembelajaran tersebut mampu memberikan pemahaman materi yang lebih baik. Berdasarkan tabel di atas pembelajaran induksi siswa yang menggunakan jumlah induktor berjumlah 4 pada RPP 1 didapatkan rata-rata 44,82 maka belum dapat dicapai ketuntasan belajar. Hal ini karena induktor yang jumlahnya sedikit belum mampu untuk memimpin kelompoknya yang berjumlah banyak. Pada RPP 2 dengan menggunakan induktor sebanyak 6 didapatkan hasil rata-rata yang lebih tinggi yaitu 65,09 lebih baik daripada RPP 1. Di RPP 2 model induksi dengan 6 induktor lebih ringan tanggungjawabnya dalam membantu anggota kelompoknya. Di RPP 3 semakin banyak induktor yaitu 8 siswa maka aktivitas siswa lebih baik yaitu 83,39. Dengan kata lain semakin banyak induktor yang digunakan maka pembelajaran akan berhasil, karena jumlah induktor yang lebih banyak dapat mengakomodasi berbagai kesulitan masing-masing kelompok dalam lingkup yang kecil. Dengan lingkup yang kecil interaksi antar siswa akan terbangun (Wardani, 2015). Syarat pembelajaran model induksi ini bisa digunakan jika guru mengetahui tingkat kemampuan siswa berdasarkan nilai hasil belajar sebelumnya. Model induksi siswa jika diterapkan pada pembelajaran kelompok dapat meningkatkan pikiran kritisnya, kreatif, dan menumbuhkan rasa sosial yang tinggi di antara temannya. Pembentukan kelompok dengan menunjuk satu induktor agar siswa dapat saling bekerja sama, saling membantu, dan saling memperhatikan satu sama lain. Hal ini berfungsi untuk saling berkolaborasi memecahkan masalah. .Siswa dituntut untuk tidak membeda bedakan temannya, yang masih memiliki tingkat pemahaman yang berbeda. Masing-masing kelompok diberikan lembar kerja siswa untuk didiskusikan. Seperti yang telah dijelaskan sebelumnya, model induksi siswa ini melalui induktornya diberikan pengertian bahwa dengan perbedaan pemahaman antar individu ini nantinya akan saling mengisi satu sama lain. Dengan adanya perbedaan pemahaman ini, siswa yang lemah akan terbantu oleh siswa yang lebih pandai 
(induktor) dan siswa yang lebih pandai akan lebih menguasai materi diakibatkan adanya rasa ingin tahu setelah mengajari teman temannya.

Tabel 5 Prosentase Analisis Penilaian Harian RPP 1

\begin{tabular}{|c|c|c|c|}
\hline \multirow[t]{2}{*}{ No } & Tujuan Pembelajaran & $\begin{array}{c}\% \\
\text { Ketuntasan } \\
\mathrm{P} \geq 76\end{array}$ & $\begin{array}{l}\text { Tuntas/Tidak } \\
\text { tuntas }\end{array}$ \\
\hline & \multicolumn{3}{|l|}{ Siswa Dapat } \\
\hline 1. & $\begin{array}{l}\text { Meyebutkan pengertian arus } \\
\text { listrik, hambatan dan beda } \\
\text { potensial }\end{array}$ & 58,8 & Tidak tuntas \\
\hline 2 & $\begin{array}{l}\text { Menyebutkan satuan besaran fisis } \\
\text { dalam listrik dinamis }\end{array}$ & 76,5 & Tuntas \\
\hline 3. & Menyebutkan bunyi hokum Ohm & 70 & Tidak Tuntas \\
\hline 4. & Menjelaskan syarat arus listrik & 42 & Tidak tuntas \\
\hline 5. & $\begin{array}{l}\text { Menjelaskan pengaruh dari } \mathrm{V} \text {, I } \\
\text { dan } \mathrm{R}\end{array}$ & 51 & Tidak Tuntas \\
\hline 6. & $\begin{array}{l}\text { Menyebutkan alat ukur beda } \\
\text { potensial, arus listrik dan } \\
\text { hambatan }\end{array}$ & 68 & Tidak Tuntas \\
\hline & Prosentase ketuntasan hasil belajar & 61,05 & Tidak tuntas \\
\hline
\end{tabular}

Tabel 6 Prosentase Analisis Penilaian Harian RPP 2

\begin{tabular}{|c|c|c|c|}
\hline No & Tujuan Pembelajaran & $\begin{array}{c}\% \\
\text { Ketuntasan } \\
\mathrm{P} \geq 76\end{array}$ & $\begin{array}{l}\text { Tuntas/Tidak } \\
\text { tuntas }\end{array}$ \\
\hline & Siswa Dapat & & \\
\hline 1. & $\begin{array}{l}\text { Mengidentifikasi antara arah } \\
\text { elektron dana rah arus }\end{array}$ & 70 & Tidak tuntas \\
\hline 2 & $\begin{array}{l}\text { Membuat skema terjadinya aliran } \\
\text { arus listrik }\end{array}$ & 68 & TidakTuntas \\
\hline 3. & Menyebutkan bunyi hokum Ohm & 76 & Tuntas \\
\hline 4. & Menjelaskan syarat arus listrik & 78 & Tuntas \\
\hline 5. & $\begin{array}{l}\text { Menghitung arus yang masuk atau } \\
\text { keluar dari titik cabang }\end{array}$ & 74 & Tidak Tuntas \\
\hline 6. & $\begin{array}{l}\text { Menghitung hambatan yang } \\
\text { disusun secara seri dan pararel }\end{array}$ & 70 & Tidak Tuntas \\
\hline & $\begin{array}{l}\text { Prosentase ketuntasan hasil } \\
\text { belajar }\end{array}$ & 72,67 & Tidak tuntas \\
\hline
\end{tabular}


Tabel 7 : Prosentase Analisis Penilaian Harian RPP 3

\begin{tabular}{|c|c|c|c|}
\hline No & Tujuan Pembelajaran & $\begin{array}{c}\% \\
\text { Ketuntasan } \\
\mathrm{P} \geq 76\end{array}$ & $\begin{array}{l}\text { Tuntas/Tidak } \\
\text { tuntas }\end{array}$ \\
\hline & Siswa Dapat & & \\
\hline 1. & $\begin{array}{l}\text { Menyusun rangkaian tertutup dan } \\
\text { terbuka }\end{array}$ & 84 & Tuntas \\
\hline 2 & $\begin{array}{l}\text { Menghitung besarnya arus listrik } \\
\text { pada titik cabang }\end{array}$ & 76 & Tuntas \\
\hline 3. & $\begin{array}{l}\text { Mengidentifikasi besarnya } \\
\text { hambatan pada rangkaian seri dan } \\
\text { pararel }\end{array}$ & 74 & $\begin{array}{l}\text { Tidak } \\
\text { Tuntas }\end{array}$ \\
\hline 4. & $\begin{array}{l}\text { Menuliskan bunyi hokum } \\
\text { Khirchoff beserta rumusnya }\end{array}$ & 86 & Tuntas \\
\hline 5. & $\begin{array}{l}\text { Menghitung beda potensial dari } \\
\text { gambar arus listrik }\end{array}$ & 80 & Tuntas \\
\hline & Prosentase ketuntasan hasil belajar & 80 & Tidak tuntas \\
\hline
\end{tabular}

Berasarkan tabel hasil analisis penilaian harian materi listrik dinamis menggunakan model induksi siswa terjadi peningkatan ketuntasan belajar di masingmasing siklus. Siklus 1 dengan rerata $61,05 \%$ siklus 2 dengan rerata 72,67 \% dan siklus 3 dengan rerata $80 \%$. Hal ini sesuai dengan penelitian Nasehudin (2013) bahwa proses pembelajaran dapat berlangsung dengan baik apabila guru mengetahui peranannya dan siswa menyadari kedudukannya, sehingga interaksi belajar-mengajar akan melahirkan hubungan yang manis, dan memungkinkan terjadinya peningkatan kualitas hasil belajar. Interaksi belajar-mengajar yang mampu melahirkan hubungan guru untuk menganalisis kebutuhan siswa, kemampuan guru memilih strategi belajarmengajar dan model mengajar yang tepat serta mempunyai kemampuan untuk mengelola kelas, jadi model induksi siswa yang dapat meningkatkan hasil belajar IPA materi listrik dinamis

\section{KESIMPULAN}

Model induksi siswa terbukti dapat meningkatkan hasil belajar siswa. Hal ini ditunjukkan dengan peningkatan rata-rata skor aktivitas belajar sebelum menggunakan model induksi mendapatkan skor rerata 43,78, kemudian pada siklus 1 skor aktivitas belajar memperoleh rerata 44,82, siklus 2 skor rerata 65,09 dan siklus 3 skor rerata 83,39 . Dan hasil ketuntasan penilaian harian siklus 1 adalah $61,05 \%$ siklus 2 adalah 72,67\% dan siklus 3 mencapai $80 \%$.

Saran penelitian bagi guru yaitu menambah pengetahuan model pembelajaran sebagai alternatif untuk meningkatkan kemampuan siswa memahami listrik dinamis. Oleh karena itu guru harus memperhatikan kemampuan masing-masing siswa sehingga dapat menentukan induktornya. Mengingat pentingnya penguasaan materi pada model induksi siswa, maka guru diharapkan harus memperhatikan kelemahan induktor- 
induktornya sehingga dapat ditutupi kesalahan-kesalahannya untuk diperbaiki di pertemuan berikutnya.

\section{DAFTAR PUSTAKA}

Abidin. 2013. Desain Sistem Pembelajaran dalam Konteks Kurikulum 2013. Bandung: Refika Aditama.

Arikunto, Suharsimi. 2014. Penelitian Tindakan Kelas. Jakarta: Bumi Aksara.

Gumrowi, A. 2016b. Strategi Pembelajaran melalui Pendekatan Kontekstual dengan Cooperative Learning untuk Meningkatkan Hasil Belajar Gelombang Siswa Kelas XII MAN 1 Bandar Lampung. Jurnal Ilmiah Pendidikan Fisika AlBiruni, 5(2), 183-191. https://doi.org/10.24042/jpifalbiruni.v5i2.118

Herlanti, Y., Rustaman, N. Y., Rohman, I., \& Fitriani, A. (2012). Kualitas Argumentasi pada Diskusi Isu Sosiosaintifik Mirobiologi melalui Weblog. Jurnal Pendidikan IPA Indonesia, 1(2), 168-177.

Hermawan, H., \& Paloloang, B. (2014). Penerapan Model Pembelajaran Kooperatif Tipe Team Assisted Individualization ( TAI ) Untuk Meningkatkan Hasil Belajar Siswa Kelas V SDN 4 Bajugan Pada Operasi Hitung Campuran. Jurnal Kreatif Tadulako Online, 4(9), 44-60.

Khusaini. (2017). Analysis of Prospective Physics Teachers' Feedback on Online PeerAssesment. Jurnal Pendidikan Fisika Indonesia, 13(1), 41-48. https://doi.org/10.15294/jpfi.v13i1.6

Nasehudin, 2013. Pengembangan Pendidikan Melalui Interaksi Pembelajaan dan Proses Komunikasi. Jurnal Pendidikan Sosial dan Ekonomi 2 (1),1

Rusman. 2013. Model-model pembelajaran: Mengembangkan Profesionalisme Guru Edisi Kedua. Jakarta: Raja Grafindo Persada.

Saregar, A., Diani, R., \& Kholid, R. (2017). Efektivitas Penerapan Model Pembelajaran ATI ( Aptitude Treatment Interaction ) Dan Model Pembelajaran TAI ( Team Assisted Individualy ) : Dampak Terhadap Hasil Belajar Fisika Siswa, 3(1), $28-35$.

Tinungki, G. M. (2015). The Role of Cooperative Learning Type Team Assisted Individualization to Improve the Students ' Mathematics Communication Ability in the Subject of Probability Theory. Journal Of Education and Practice, 6(32), 27-31.

Wardani, N. C. A., Suwatra, I. W., \& Wirya, N. (2015). Pengaruh Model Pembelajaran Team Assisted Individualization ( TAI ) terhadap Hasil Belajar Mata Pelajaran IPA pada Siswa Kelas VII Tahun Ajaran 2014/2015 di SMP NEGERI 1 BANJAR. Jurnal Edutech, 2(1).

Yulianti, D., \& Putra, N. M. D. (2012). Upaya Mengembangkan Learning Community Siswa Kelas X SMA melalui Penerapan Model Pembelajaran Kooperatif Tipe STAD Berbasis CTL pada Pembelajaran Fisika. Jurnal Pendidikan IPA Indonesia, 1(1), 57-62. 